\title{
Influence of Various Levels of Organic Zinc on the Live Performance, Meat Quality Attributes, and Sensory Properties of Broiler Chickens
}

\author{
Hossan Md. Salim ${ }^{1,2}$, Hak Rim Lee ${ }^{1}$, Cheorun Jo1 , Soo Kee Lee ${ }^{1}$, and Bong Duk Lee ${ }^{1 *}$ \\ ${ }^{1}$ Department of Animal Science and Biotechnology, Chungnam National University, Daejeon 305-764, Korea \\ ${ }^{2}$ Poultry Science Division, National Institute of Animal Science, Cheonan 330-801, Korea
}

\begin{abstract}
The influence of supplementing diets with various levels of organic zinc (OZ) on the performance, meat quality attributes, and sensory properties of broiler chickens was investigated. A total of 3,200 1-d-old female broiler chicks were randomly allotted to 16 floor pens (replicates) with 200 birds per pen. A corn-wheat-soybean meal basal diet (control) was formulated and $20 \mathrm{ppm} \mathrm{OZ}(20 \mathrm{OZ}), 40 \mathrm{ppm} \mathrm{OZ}(40 \mathrm{OZ})$, or $80 \mathrm{ppm} \mathrm{OZ}(80 \mathrm{OZ})$ was added to the basal diet to form four dietary treatments with four replicates per treatment. Live performance of broiler chickens, meat quality, and sensory properties were evaluated. The results showed no significant difference among the treatments for live performance of broiler chickens. Significant increases $(p<0.05)$ in thigh skin epidermis and dermis thickness were shown in the OZ supplementation groups; however, no effect of OZ on the thickness of back skin epidermis or dermis was found. Dietary OZ levels did not affect the $\mathrm{pH}$ of breast and thigh meat or the water holding capacity (WHC) of thigh meat, but the WHC of breast meat increased significantly $(p<0.05)$ when birds were fed $40 \mathrm{OZ}$ and $80 \mathrm{OZ}$. Results of a sensory analysis showed no differences among the dietary treatments. In conclusion, dietary $\mathrm{OZ}$ did not affect live performance or sensory properties of broiler chickens but did increase the WHC of breast meat and thickness of skin layers; thus, improving carcass quality in broiler chickens.
\end{abstract}

Key words: organic zinc, live performance, meat quality attributes, sensory properties, broilers

\section{Introduction}

Zinc is a trace mineral that is required for the normal growth, development and function of all living organisms. In chicken, zinc is needed for growth, feathering, skeletal development, immunity, meat yields, and carcass quality (Bonimi et al., 1983; Pinion et al., 1995; Stahl et al., 1989). Zinc deficiency causes reduction in weight gain, poor bone mineralization, increases skin lesions and poor wound healing in chicken (Scott et al., 1982; Young et al., 1958). El Swak et al. (1992) reported that wound healing was slower in zinc deficient rats than zinc supplemented rats. Moreover, zinc plays a vital role in the production of epithelial cells (Costa, 2005), skin nucleic acid, keratin, and collagen synthesis (Miller et al., 1979).

Collagen is the principle structural component of skin which is mainly responsible for the skin layer thickness and strength. Tensile strength of skin is highly correlated

\footnotetext{
*Corresponding author: Bong Duk Lee, Department of Animal Science and Biotechnology, Chungnam National University, Daejeon 305-764, Korea. Tel: 82-42-821-5778, Fax: 82-42825-9754, E-mail: leebd@cnu.ac.kr
}

to skin tearing which is a costly problem in the broiler industry resulting in downgrades of broilers (Angel et al., 1985; Schleifer, 1988). In severe cases frequency of skin tearing increases about $60 \%$ in a flock (Cahaner et al., 1993 ) and may cause muscle shredding of up to $5.7 \%$ in the female birds (Pitcovski et al., 1994). Skin tears also allow carcasses to absorb additional moisture in the chill tank that may reduce shelf life of meat. The superoxide dismutase, one of the zinc-containing antioxidant enzymes, has a critical role in keeping broiler skin healthy and increasing the shelf life of broiler meat (Salim et al., 2008). In addition, over the last few years, consumer demands regarding broilers with good quality skin have substantially increased in the markets.

Broiler carcass appearance is the major criterion of evaluation of meat quality and consumer purchase. However, other quality attributes, such as tenderness, cook loss, water holding capacity (WHC), $\mathrm{pH}$ and sensory properties are equally important during the preparation of meat and meat products (Cross et al., 1986). Raw meat used in further processed products should have good functional properties to ensure a final product of exceptional quality and profitability. 
Recently, a compound containing organic zinc (OZ), zinc proteinate, was made available to the feed industry. It has been reported that the addition of zinc proteinate as $\mathrm{OZ}$ to the diets of broilers could increase $\mathrm{BW}$, feed intake, feed efficiency (Ao et al., 2009), and carcass quality (Salim et al., 2010). In fact, organic minerals chelated to small peptides have much greater bioavailability through increased selective transport of peptides at the gut level (Webb et al., 2005) and reduced excretion through droppings (Bao et al., 2007). An experiment conducted in our laboratory has shown that dietary $\mathrm{OZ}$ was more effective than inorganic zinc in the improvement of skin zinc concentration and skin quality of broiler chickens (Salim et al., 2010). Rossi et al. (2007) reported that a reduction in skin tearing was observed by the addition of $\mathrm{OZ}$ in the broiler diets which would improve carcass appearance. The authors also found that live performance, carcass and cut-up yield of broiler chickens were not influenced by various levels of dietary OZ. On the other hand, Hess et al. (2001) concluded that the influence of $\mathrm{OZ}$ on broiler chicken live performance, carcass bruising and foot pad quality appeared to vary with environmental conditions. However, various levels of dietary OZ supplementation effects on skin and meat quality attributes, and sensory properties of broiler chickens are not available. Thus, the present experiment was conducted to investigate the influence of supplementing diets with various levels of $\mathrm{OZ}$ on the live performance, meat quality, and sensory properties of broiler chickens.

\section{Materials and Methods}

\section{Experimental birds, diets and treatments}

Three thousand and two hundred 1-d-old female broiler chicks (Ross $\times$ Ross 308 ) were randomly assigned to 16 rice hull-littered floor pens (replicates) with 200 chicks per pen $\left(0.093 \mathrm{~m}^{2} / \mathrm{bird}\right)$. Continuous lighting was provided throughout the experimental period. The initial room temperature was $32^{\circ} \mathrm{C}$, and reduced by $3^{\circ} \mathrm{C}$ each wk until $35 \mathrm{~d}$ of age. Chicks were allowed free access to feed and water throughout 5 wk feeding period. All procedures were approved by the Animal Care and Welfare Committee of Chungnam National University, Korea. As shown in Table 1, a corn-wheat-soybean meal basal diet (Control) was formulated and $20 \mathrm{ppm} \mathrm{OZ} \mathrm{(20} \mathrm{OZ),} 40$ ppm OZ (40 OZ), and $80 \mathrm{ppm} \mathrm{OZ} \mathrm{(80} \mathrm{OZ)} \mathrm{were} \mathrm{added} \mathrm{to}$ the basal diet to give four dietary treatments. The basal diet was formulated to either meet or exceed the National Research Council requirements (NRC, 1994) except zinc,
Table 1. Composition of the basal (Control) diet

\begin{tabular}{|c|c|}
\hline Ingredients & Amount (\%) \\
\hline Corn & 25.78 \\
\hline Wheat & 30.00 \\
\hline Soybean meal & 22.99 \\
\hline Rape seed meal & 3.00 \\
\hline DDGS $^{1}$ & 10.00 \\
\hline Yellow Grease & 4.26 \\
\hline DL-Methionine & 0.30 \\
\hline L-Lysine (98\%) & 0.38 \\
\hline L-Threonine (98\%) & 0.08 \\
\hline Salt & 0.23 \\
\hline Limestone & 1.79 \\
\hline Monocalcium phosphate & 0.66 \\
\hline Phyzyme & 0.05 \\
\hline Mineral mixture $^{2}$ & 0.20 \\
\hline Vitamin mixture $^{3}$ & 0.05 \\
\hline Choline chloride & 0.12 \\
\hline Salinomysine & 0.10 \\
\hline Avylamycine & 0.03 \\
\hline Total & 100.0 \\
\hline \multicolumn{2}{|l|}{ Calculated composition } \\
\hline Crude protein (\%) & 20.11 \\
\hline $\mathrm{ME}(\mathrm{kcal} / \mathrm{kg})$ & 3,070 \\
\hline $\mathrm{Ca}(\%)$ & 0.99 \\
\hline Total P (\%) & 0.55 \\
\hline Available P (\%) & 0.48 \\
\hline Lysine (\%) & 1.24 \\
\hline Methionine (\%) & 0.61 \\
\hline
\end{tabular}

${ }^{1}$ Corn distillers dried grains with soluble

${ }^{2}$ Mineral mixture supplied per kilogram of complete feed: iron, $146 \mathrm{mg}$; copper, $72 \mathrm{mg}$; iodine, $0.95 \mathrm{mg}$; selenium, $0.4 \mathrm{mg}$; manganese, $89 \mathrm{mg}$

${ }^{3}$ Vitamin mixture supplied per kilogram of complete feed: vitamin A, $12000 \mathrm{IU}$; vitamin $\mathrm{D}_{3}, 3,000 \mathrm{IU}$; vitamin E, $32 \mathrm{mg}$; vita$\min \mathrm{K}_{3}, 2.06 \mathrm{mg}$

Table 2. Analyzed zinc concentrations in the experimental diets for broiler chickens ( 8 to $35 \mathrm{~d}$ )

\begin{tabular}{cc}
\hline \hline Treatments $^{1}$ & Dietary zinc $(\mathrm{ppm})^{2}$ \\
\hline Control & $33.57 \pm 0.56$ \\
OZ 20 & $54.56 \pm 0.95$ \\
OZ 40 & $74.06 \pm 0.78$ \\
OZ 80 & $113.66 \pm 1.06$
\end{tabular}

${ }^{1}$ Control, without zinc supplement; OZ 20, organic zinc 20 ppm; OZ 40, organic zinc $40 \mathrm{ppm}$; OZ 80, organic zinc $80 \mathrm{ppm}$

${ }^{2}$ Values(means $\pm \mathrm{SD} ; \mathrm{n}=3$ ) are as-fed basis. 
and fed for the first $7 \mathrm{~d}$ to all birds. Chicks were fed experimental diets for the next $28 \mathrm{~d}$. The OZ source was zinc proteinate (Bioplex Zn, Alltech Inc., Nichoasville, KY, USA) that contained $15 \%$ zinc. Analyzed zinc concentrations of experimental diets by AOAC (2000) are presented in Table 2.

\section{Live performance}

The BW and feed intake were measured by pen at weekly intervals. Feed conversion was calculated as the feed to gain ratio. Livability of bird was recorded daily and calculated as percentage within the pen. The European production efficiency factor (EPEF) was calculated according to the following formula (Peric et al., 2009):

$$
\begin{aligned}
\mathrm{EPEF}= & (\mathrm{BW}(\mathrm{g}) \times \text { survival rate }(\%)) \\
& \div(\text { feed conversion } \times \text { duration of trial }(\mathrm{d})) \times 10 .
\end{aligned}
$$

\section{Measurement of skin layer thickness}

At the end of the feeding trial, one broiler chicken from each pen, close to the mean BW, was selected and killed by cervical dislocation. Then about $1 \mathrm{~cm}^{2}$ of skin samples from the outer side of left and right thigh and the pelvic back region of each broiler chicken were collected. The samples were fixed in 10\% neutral formalin $(\mathrm{pH} 7.4)$, dehydrated in a graded series of ethanol and embedded in paraffin, after which 4- $\mu$ m-thick sections were stained with hematoxylin and eosin. Thickness of skin layers (epidermis and dermis) were examined $(\times 100)$ under a light microscope (Olympus Co. Ltd., BX 50, F-3, Japan) with a camera (Focus Light, Version 2.88). Only the thinnest part of the skin layer was measured on each of skin replicates from a treatment.

\section{Sample collection for carcass evaluation}

At the end of the feeding trial, two broiler chickens from each pen, close to the mean BW, were weighed, exsanguinated by cutting the jugular vein, scalded, plucked, and eviscerated manually. Meat samples were collected and stored about one mon at $-20^{\circ} \mathrm{C}$ in a deep freezer (Sanyo Electric Co., Ltd. MDF-492, Japan). Vacuumpacked meat samples were thawed by heating for $20 \mathrm{~min}$ at $35^{\circ} \mathrm{C}$ in a water bath and the $\mathrm{WHC}, \mathrm{pH}$, and sensory evaluation were performed.

\section{Determination of water holding capacity (WHC)}

The centrifugation method was performed for the determination of WHC of breast and thigh meat as described by Kristensen and Purslow (2001) with some modifica- tions. One gram of ground meat was placed on a round filter paper (No.4, Whatman Ltd. UK). The filter paper with meat was put into centrifuge tubes (Mobicols from MoBiTec, Göttingen) and centrifuged (CR 20B2, Hitachi Koki Co., Ltd., Japan) at 6,710 g for $10 \mathrm{~min}$. The released water content was measured and calculated as percentage of the initial moisture content of meat.

\section{Determination of $\mathbf{p H}$}

One gram each of ground breast and thigh meat was homogenized in $900 \mu \mathrm{L}$ of distilled water and then centrifuged (CR 20B2, Hitachi Koki Co., Ltd. Japan) at 3,000 g for $15 \mathrm{~min}$. The sample was placed on a round filter paper (No.4, Whatman Ltd. UK) and the $\mathrm{pH}$ of the homogenate was measured using a pH meter (Model 750 P, ISTEC, Seoul, Korea).

\section{Sensory analysis}

Sensory panel tests were carried out for the cooked breast and thigh meat without skin. Ten panelists were selected from the meat science laboratory of our department and all had experience in poultry meat sensory analysis. Criteria for selection were: age between 20 to 40 years, not allergic to chicken, consumption of chicken at least once a wk, and willingness to evaluate meat from experimental chickens. Chicken breast and thigh meat contained in the air tied vinyl bags were thawed by heating for $20 \mathrm{~min}$ at $35^{\circ} \mathrm{C}$ in a water bath. The bags were then opened and pieces of meat (30 g each) were placed in screw-capped flasks. These were heated at $75^{\circ} \mathrm{C}$ for 20 min in a $177^{\circ} \mathrm{C}$ electric oven and served to the panelists. Samples from all dietary treatments were randomly presented to each panelist in one session. They were asked to rank the meat samples using a 9-point category hedonic scale $(1=$ dislike extremely; $5=$ neither like nor dislike; $9=$ like extremely) (Peryam and Girardot, 1952). Sensory analysis included seven characteristics such as color, odor, taste, tenderness, juiciness, flavor, and acceptability. Water and unsalted crackers were provided to clean their plates between samples.

\section{Statistical analyses}

Data from the experiment were analyzed by one-way ANOVA using the General Linear Models procedure of the Statistical Analysis System (SAS, 2003). Pen means were used as the experimental units for all variables evaluated. When significant $(p<0.05)$, treatment means were compared using the Duncan's multiple range test procedure. 


\section{Results and Discussion}

During the entire feeding trial period no significant differences were observed among treatments for any performance parameter or EPEF measurements of birds (Table 3). A numeric, but not significant, difference in feed conversion was observed only for the broilers fed OZ 80 at $35 \mathrm{~d}$ of age. Hess et al. (2001) reported that feed conversion was improved for broiler chickens fed zinc methionine at $35 \mathrm{~d}$ of age, and for male broilers at $21 \mathrm{~d}$ of age. These authors also found significant improvement in BW of male broilers at $21 \mathrm{~d}$ of age, when birds fed zincmethionine and zinc-lysine as complexed zinc products. Similarly, Ao et al. (2009) reported that dietary supplementation of zinc from organic source was increased BW, feed intake, and feed conversion of chicks. However, previous studies with inorganic zinc (Mehring et al., 1956; Wang et al., 2002), and with organic zinc (Hudson et al., 2004; Rossi et al., 2007), indicated that growth performance, leg abnormalities, and carcass yields were unaffected when dietary zinc were provided in excess of the NRC (1994) recommendations of $40 \mathrm{ppm}$. However, the actual zinc concentrations in the supplemented groups of the present experiment were 54.56, 74.06, and 113.66 ppm, which was higher than the NRC (1994) recommendations.

The back skin epidermis and dermis thickness were not influenced by OZ supplementation, but the thickness of thigh skin epidermis was significantly increased $(\mathrm{P}<$ 0.05) in OZ 80 as compared with Control and OZ 20 (Table 4). Moreover, significant increases $(\mathrm{P}<0.05)$ in thigh skin dermis was observed in response to various levels of OZ supplementations (Table 4; Fig. 1). Another study conducted in our laboratory has shown that dietary $\mathrm{OZ}$ supplementation significantly increased the tibia and back skin dermis thickness of broiler chickens (Salim et al., 2010). The authors also reported that the epidermis of tibia and back skin were not affected by the zinc supplementation, which is not in agreement with the thigh skin epidermis data of the present experiment. However, Rossi et al. (2007) observed that the number of epithelial cell layers was increased with increasing levels of $\mathrm{OZ}$ in the diet of broiler chickens.

Zinc is necessary for the production of epithelial cells (Costa, 2005), the first barrier to infection (Johnson et al., 2001). Zinc also plays a role in collagen synthesis (Leeson and Summers, 2005) and the thickness of the dermis layer depends on the collagen content in the skin. Normally, the skin has two main layers; a) epidermis which is covering the exterior surface of the body, and b) the deeper layer called the dermis which is mainly composed of connective tissue, collagen. Collagen is the principle structural protein of skin and is responsible for the skin strength in a variety of species (Harkness, 1971; Fjolstad

Table 3. Effect of various levels of organic zinc (OZ) on live performance of broiler chickens (2-5 wk)

\begin{tabular}{llllll}
\hline \multirow{2}{*}{ Item } & \multicolumn{2}{c}{ Treatment $^{1}$} & OZ 80 & \\
\cline { 2 - 5 } & \multicolumn{1}{c}{ Control } & OZ 20 & OZ 40 & Olue \\
\hline BW gain, g/bird & $1,599 \pm 4$ & $1,560 \pm 7$ & $1,602 \pm 7$ & $1,574 \pm 2$ & 0.568 \\
Feed intake, g/bird & $2,525 \pm 18$ & $2,462 \pm 19$ & $2,563 \pm 42$ & $2,524 \pm 43$ & 0.328 \\
Feed/gain & $1.59 \pm 0.06$ & $1.59 \pm 0.02$ & $1.57 \pm 0.01$ & $1.55 \pm 0.04$ & 0.327 \\
Livability, \% & $96 \pm 1.3$ & $96 \pm 1.0$ & $95 \pm 1.5$ & $97 \pm 1.0$ & 0.232 \\
EPEF & $292 \pm 16$ & $284 \pm 12$ & $294 \pm 11$ & $300 \pm 10$ & 0.502 \\
\hline
\end{tabular}

${ }^{1}$ See Table 2

${ }^{2}$ Values are expressed as (means $\pm \mathrm{SD} ; \mathrm{n}=800$ )

${ }^{3} \mathrm{EPEF}$, European production efficiency factor

Table 4. Skin layer thickness $(\mu \mathrm{m})$ of broiler chickens fed various levels of organic zinc $(\mathrm{OZ})$

\begin{tabular}{ccccc}
\hline \hline \multirow{2}{*}{ Treatments $^{1}$} & \multicolumn{2}{c}{ Back skin } & \multicolumn{2}{c}{ Thigh skin } \\
\cline { 2 - 5 } & Epidermis & Dermis & Epidermis & Dermis \\
\hline Control & $21.28 \pm 3.91^{2}$ & $71.36 \pm 3.22$ & $19.15 \pm 3.70^{\mathrm{b}}$ & $65.98 \pm 3.88^{\mathrm{b}}$ \\
OZ 20 & $22.16 \pm 0.95$ & $76.19 \pm 15.63$ & $18.51 \pm 0.86^{\mathrm{b}}$ & $87.80 \pm 10.01^{\mathrm{a}}$ \\
OZ 40 & $22.07 \pm 0.86$ & $78.64 \pm 9.25$ & $21.44 \pm 1.52^{\text {ab }}$ & $88.13 \pm 5.33^{\mathrm{a}}$ \\
OZ 80 & $25.79 \pm 3.77$ & $82.51 \pm 17.93$ & $24.45 \pm 1.47^{\mathrm{a}}$ & $83.22 \pm 15.19^{\mathrm{a}}$ \\
\hline
\end{tabular}

\footnotetext{
${ }^{1}$ See Table 2

${ }^{2}$ Values are expressed as (means $\pm \mathrm{SD} ; \mathrm{n}=4$ )

${ }^{a-b}$ Means with different superscripts in the same column differ significantly $(p<0.05)$.
} 


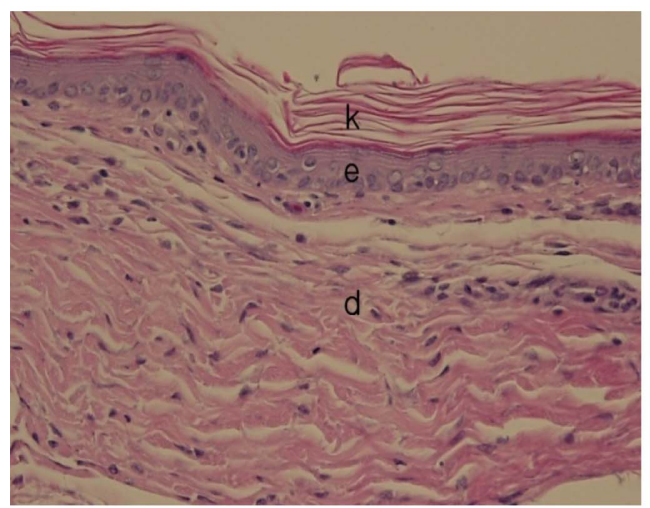

(a)

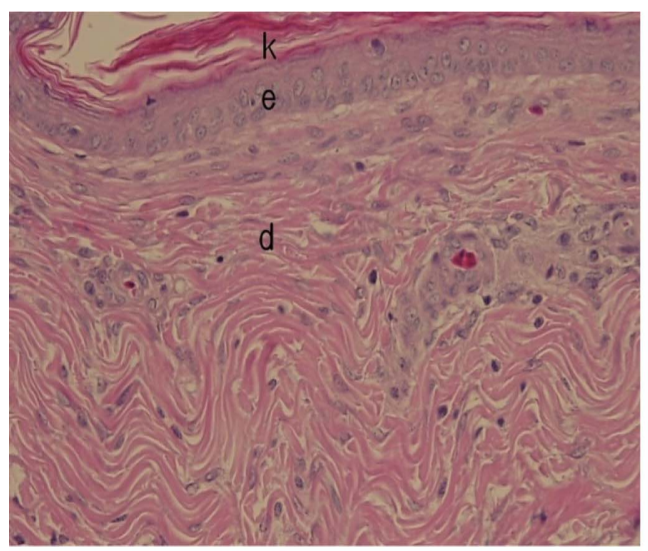

(c)

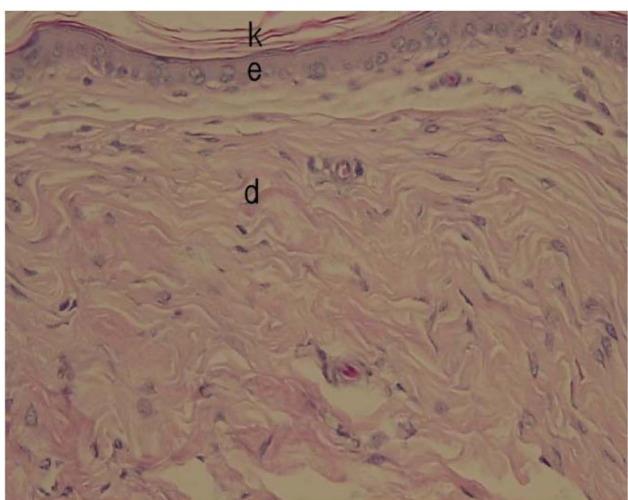

(b)

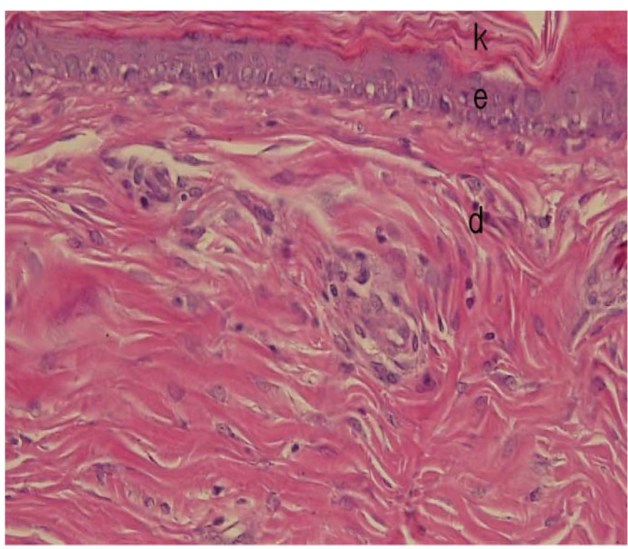

(d)

Fig. 1. Slides showing the thickness of epidermis and dermis of thigh skin from broiler chickens fed various levels of organic zinc (OZ) supplementation. (a) Control; (b) OZ 20 ppm; (c) OZ 40 ppm; (d) OZ 80 ppm. (k, keratin; e, epidermis; d, dermis).

and Helle, 1974). Rossi et al. (2007) reported that collagen content of skin was increased when birds fed higher levels of OZ. Similarly, a previous study conducted in our laboratory has shown that dietary $\mathrm{OZ}$ supplementation significantly increased the collagen contents in the back skin of broiler chickens (Salim et al., 2010). Therefore, the thicker epidermis and dermis layers may be due to increased production of epithelial cells and collagen content in the skin, and more developed skin layers may indicate healthy broiler skin with good appearance of carcass.

Dietary OZ levels did not affect the $\mathrm{pH}$ of breast and thigh meats, and WHC of thigh meat, but the WHC of breast meat increased significantly $(p<0.05)$ when birds fed $\mathrm{OZ} 40$ and $\mathrm{OZ} 80$ (Table 5). The $\mathrm{pH}$ and WHC are considered to be important characteristics in evaluating meat quality. Generally, the $\mathrm{pH}$ value directly reflects meat acid content, and affects shear force, drip loss, and color of meat. Muscle $\mathrm{pH}$ is also related to glycogenolysis, and increased catecholamine secretion in response to an acute stressor just prior to slaughter.
The WHC can affect the taste, tenderness, color, fragrance, and nutrient content of meat and meat products (Tian and Yu, 2001). Lower WHC in meat can increase intracellular fluid out flow, loss of soluble nutrients and flavor. It also reduces the juiciness of the cooked product and makes unfavorable appearance of packaged meat. Saenmahayak (2007) reported that WHC of breast meat was not significantly influenced by different sources of zinc which is not agreement with the present study. The author also indicated that a numerical trend of improvement of WHC of breast meat was observed when birds fed various ratios of supplemental manganese versus zinc (Saenmahayak, 2007). Zinc act as an antioxidant (Rostan et al., 2002) that can reduce oxidation in the muscle tissue. Increased levels of oxidation can damage cell membranes, reducing their integrity and allowing seepage of intracellular fluids. Therefore, increased WHC of breast meat in the present experiment may be due to the antioxidant capability of zinc (Aksu et al., 2010; Rostan et al., 2002), and further research is needed to draw a conclu- 
Table 5. The pH and Water holding capacity (WHC) of meats of broiler chickens fed various levels of organic zinc (OZ)

\begin{tabular}{ccccc}
\hline \multirow{2}{*}{ Treatments $^{1}$} & \multicolumn{2}{c}{$\mathrm{pH}$} & \multicolumn{2}{c}{ WHC (\%) } \\
\cline { 2 - 5 } & Breast meat & Thigh meat & Breast meat & Thigh meat \\
\hline Control & $6.2 \pm 0.01^{2}$ & $6.7 \pm 0.02$ & $56.2 \pm 2.32^{\mathrm{b}}$ & $60.5 \pm 2.21$ \\
OZ 20 & $6.0 \pm 0.02$ & $6.5 \pm 0.01$ & $56.3 \pm 5.39^{\mathrm{b}}$ & $56.7 \pm 1.19$ \\
OZ 40 & $6.0 \pm 0.01$ & $6.5 \pm 0.02$ & $66.0 \pm 4.80^{\mathrm{a}}$ & $54.4 \pm 4.35$ \\
OZ 80 & $6.1 \pm 0.01$ & $6.5 \pm 0.01$ & $62.6 \pm 5.19^{\mathrm{a}}$ & $60.6 \pm 6.49$ \\
\hline
\end{tabular}

${ }^{1}$ See Table 2 .

${ }^{2}$ Values are expressed as (means $\pm \mathrm{SD} ; \mathrm{n}=8$ ).

${ }^{\mathrm{a}, \mathrm{b}}$ Means with different superscripts in the same column differ significantly $(p<0.05)$.

Table 6. Sensory properties of breast meat of broiler chickens fed various levels of organic zinc (OZ)

\begin{tabular}{|c|c|c|c|c|c|}
\hline \multirow{2}{*}{ Properties } & \multicolumn{4}{|c|}{ Treatments $^{1}$} & \multirow{2}{*}{$p$ value } \\
\hline & Control & OZ 20 & $\mathrm{OZ} 40$ & OZ 80 & \\
\hline Color & $4.89 \pm 0.60^{2}$ & $4.89 \pm 1.76$ & $4.56 \pm 1.88$ & $5.11 \pm 1.96$ & 0.660 \\
\hline Odor & $5.00 \pm 1.32$ & $5.00 \pm 1.58$ & $5.22 \pm 1.86$ & $5.67 \pm 1.22$ & 0.427 \\
\hline Taste & $4.89 \pm 1.05$ & $5.11 \pm 1.69$ & $5.22 \pm 1.39$ & $5.89 \pm 1.05$ & 0.445 \\
\hline Tenderness & $5.00 \pm 1.00$ & $5.67 \pm 1.41$ & $5.22 \pm 1.20$ & $5.33 \pm 1.41$ & 0.428 \\
\hline Juiciness & $4.56 \pm 1.24$ & $5.67 \pm 1.66$ & $4.89 \pm 1.27$ & $5.11 \pm 1.36$ & 0.201 \\
\hline Flavor & $4.67 \pm 1.50$ & $5.22 \pm 1.39$ & $5.44 \pm 1.42$ & $6.00 \pm 0.71$ & 0.732 \\
\hline Acceptability & $4.78 \pm 0.97$ & $5.56 \pm 1.51$ & $5.00 \pm 1.50$ & $5.67 \pm 1.22$ & 0.334 \\
\hline
\end{tabular}

${ }^{1}$ See Table 2.

${ }^{2}$ Values are expressed as (means $\left.\pm \mathrm{SD} ; \mathrm{n}=10\right)$.

Table 7. Sensory properties of thigh meat of broiler chickens fed various levels of organic zinc (OZ)

\begin{tabular}{lccccc}
\hline \hline \multirow{2}{*}{ Properties } & \multicolumn{2}{c}{ Treatments $^{1}$} & \\
\cline { 2 - 5 } & Control & OZ 20 & OZ 40 & OZ 80 & \\
\hline Color & $3.78 \pm 1.39^{2}$ & $4.22 \pm 1.20$ & $4.44 \pm 1.56$ & $4.56 \pm 1.42$ & 0.634 \\
Odor & $4.44 \pm 1.42$ & $4.89 \pm 1.36$ & $4.44 \pm 1.81$ & $5.00 \pm 1.94$ & 0.732 \\
Taste & $5.11 \pm 1.17$ & $5.33 \pm 1.50$ & $5.33 \pm 0.71$ & $5.56 \pm 1.88$ & 0.427 \\
Tenderness & $6.33 \pm 1.32$ & $6.33 \pm 0.87$ & $6.11 \pm 1.05$ & $6.44 \pm 1.51$ & 0.399 \\
Juiciness & $5.78 \pm 1.09$ & $5.89 \pm 0.78$ & $6.44 \pm 0.88$ & $6.00 \pm 1.66$ & 0.445 \\
Flavor & $5.00 \pm 1.12$ & $5.42 \pm 1.42$ & $5.22 \pm 1.09$ & $6.22 \pm 2.05$ & 0.428 \\
Acceptability & $5.33 \pm 1.32$ & $5.33 \pm 1.41$ & $5.67 \pm 0.71$ & $6.33 \pm 2.12$ & 0.201 \\
\hline
\end{tabular}

${ }^{1}$ See Table 2 .

${ }^{2}$ Values are expressed as (means $\pm \mathrm{SD} ; \mathrm{n}=10$ ).

sion on the effect of organic zinc in the WHC, $\mathrm{pH}$, and thiobarbituric acid reactive substances (TBARS) values of broiler meats. However, Petrovic et al. (2009) reported that the peroxide and TBARS value decreased in breast and thigh meat of broiler chickens were fed proteinated forms of trace minerals including zinc. Furthermore, previous experiments have shown that feeding organic Se can reduce drip loss in broilers (Edens et al., 1996; Deniz et al., 2005), and breast meat has better WHC than chicken thigh meat (Smolinksa and Korzeniowska, 2005).

The effects of OZ supplementation on sensory properties (color, odor, taste, tenderness, juiciness, flavor, and acceptability) of breast and thigh meat were shown in
Table 6 and Table 7. There were no significant differences in sensory properties of breast and thigh meats among all treatments. Bou et al. (2004) reported that zinc supplementation showed no effect on consumer acceptability and 2-thiobarbituric acid (TBA) values of cooked dark chicken meat after 5 mon of storage at $-20^{\circ} \mathrm{C}$. Similarly, in a later study, Bou et al. (2005) also found that zinc supplementation did not affect the sensory quality or TBA values for either storage time. Therefore, our sensory analysis data are consistent with these studies conducted by Bou et al. (2004 and 2005). It is concluded that dietary $\mathrm{OZ}$ does not affect live performance and sensory properties of broiler chickens, but increases WHC of 
breast meat and skin layer thickness. The thickened skin layer could improve skin strength and shelf life of meat, thereby improving meat quality of broiler chickens.

\section{Acknowledgments}

The authors thank Dr. S. W. Cho, Department of Pathology, College of Veterinary Medicine, Chungnam National University for his supervision in skin tissue preparation and reading. Support from the Meat Science Laboratory of the Department of Animal Science and Biotechnology for analyze the experimental sample is highly appreciated.

\section{References}

1. Aksu, D. S., Aksu, T., Ozsoy, B., and Baytok, E. (2010) Effects of replacing inorganic with a lower level of organically complexed minerals ( $\mathrm{Cu}, \mathrm{Zn}$ and $\mathrm{Mn})$ in broiler diets on lipid peroxidation and antioxidant defense systems. AsianAust. J. Anim. Sci. 23, 1066-1072.

2. Angel, S., Weinberg, Z. G., Polisluk, O., Heit, M., Plavnik, I., and Bartov, I. (1985) A connection between a dietary coccidiostat and skin tears of female broiler chickens. Poult. Sci. 64, 294-296.

3. Ao, T., Pierce, J. I., Power, R., Pescator, A. J., Cantor, A. H., Dawson, K. A., and Ford, M. J. (2009) Effects of feeding different forms of zinc and copper on the performance and tissue mineral content of chicks. Poult. Sci. 88, 2171-2175.

4. AOAC (2000) Official methods of analysis. 17th ed, Association of Official Analytical Chemists, Washington, DC.

5. Bao, Y. M., Choct, M., Iji, P. A., and Brueton, K. (2007) Effect of organically complexed copper, iron, manganese, and zinc on broiler performance, mineral excretion, and accumulation in tissues. J. Appl. Poult. Res. 16, 448-455.

6. Bonimi, A., Quarantelli, A., Superchi, P., Sabbioni, A., and Lucchelli, L. (1983) Chelated trace element complexes in the feeding of broiler chicken. Annali-della-Facolta-di-Medicina-Veterinaria-di-Parma. 3, 103-118.

7. Bou, R., Guardiola, F., Tres, A., Barroeta, A. C., and Codony, R. (2004) Effect of dietary fish oil, tocopheryl acetate, and zinc supplementation on the composition and consumer acceptability of chicken meat. Poult. Sci. 83, 282-292.

8. Bou, R., Guardiola, F., Barroeta, A. C., and Codony, R. (2005) Effect of dietary fat sources and zinc and selenium supplements on the composition and consumer acceptability of chicken meat. Poult. Sci. 84, 1129-1140.

9. Cahaner, A., Gutman, M., and Pines, M. (1993) Genetic and phenotypic association between skin tearing and skin collagen, protein, and fat in broilers. Poult. Sci. 72, 1832-1840.

10. Costa, M. A. G. (2005) O papel do zinco e do cromo no desempenho das porcas. In: Porkworld ano 4, no. 26 (maio/ junho). AUTH QUERY: Is Porkworld a magazine? Animal World, Paulý'nia, Sa o Paulo, Brazil, pp. 58-60.
11. Cross, H. R., Durland, P. R., and Seideman, S. C. (1986) Sensory qualities of meat. In: Muscles as Food, Academic Press, NY, pp. 279-320.

12. Deniz, G., Genzen, S. S., and Turkman, I. I. (2005) Effects of two supplemental dietary selenium sources (mineral and organic) on broiler performance and drip-loss. Rev. Med. Vet. 156, 423-426.

13. Edens, F. W., Carter, T. A., and Sefton, A. E. (1996) Influence of dietary selenium sources on post mortem drip loss from breast meat of broilers grown on different litters. Poult. Sci. 75, 60 .

14. El Swak, A. A., El Katche, M. I., El Bayomi, K. M., Ismail, E. Y., and Banna, E. S. (1992) Effect of certain nutrients on skin wound healing in laboratory rats. I. Effect of zinc deficiency and zinc supplementation. Egyptian J. Com. Patho. and Clin. Pathol. 5, 109-121.

15. Fjolstad, M. and Helle, O. (1974) A hereditary dysplasia of collagen tissues in sheep. J. Pathol. 112, 183-188.

16. Harkness, R. D. (1971) Mechanical properties of skin in relation to its biological function and its chemical components. In: Biophysical properties of the skin. Elden, H. R. (ed.) Wiley-Interscience, NY, pp. 394-436.

17. Hess, J. B., Bilgili, S. F., Parson, A. M., and Downs, K. M. (2001) Influence of complexed zinc products on live performance and carcass grade of broilers. J. Appl. Anim. Res. 19, 49-60.

18. Hudson, B. P., Fairchild, B. D., and Wilson, J. L. (2004) Breeder age and zinc source in broiler breeder hen diets on progeny characteristics at hatching. J. Appl. Poult. Res. 13, 55-64.

19. Johnson, R. W., Escobar, J., and Webel, D. M. (2001) Nutrition and immunology of swine. In: Swine Nutrition. Lewis, A. J. and Southern, L. L. (ed.) CRC Press, Boca Raton, FL, pp. 545-562.

20. Kristensen, L. and Purslow, P. P. (2001) The effect of ageing on the water-holding capacity of pork: role of cytoskeletal proteins. Meat Sci. 58, 17-23.

21. Leeson, S., and Summers, J. D. (2005) Commercial Poultry Nutrition. Univ. Books, Guelph, Ontario, Canada.

22. Mehring, A. L., Brumbaugh, J. H., and Titus, H. W. (1956) A comparison of the growth of chicks fed diets containing different quantities of zinc. Poult. Sci. 35, 956-958.

23. Miller, E. R., Stowe, H. D., Ku, P. K., and Hill, G. M. (1979) In: Copper and zinc in animal nutrition. Literature Review Committee, National Feed Ingredients Association, West Des Moines, IA.

24. National Research Council (1994) Nutrient requirements of poultry. 9th ed. Natl. Acad. Press, Washington, DC.

25. Peric, L., Milosevic, N., Zikic, D., Kanacki, Z., Dzinic, N., Nollet, L., and Spring, P. (2009) Effect of selenium sources on performance and meat characteristics of broiler chickens. J. Appl. Poult. Res. 18, 403-409.

26. Peryam, D. R. and Girardot, N. (1952) Advanced taste-tes method. Food Eng. 24, 58-61.

27. Petrovic, V., Marcincak, S., popelka, P., Nollet, L., and Kovac, G. (2009) Effect of dietary supplementation of trace 
elements on the lipid peroxidation in broiler meat assessed after a refrigerated and frozen storage. J. Anim. Feed Sci. 18, 499-507.

28. Pinion, J. L, Bilgili, S. F., and Hess, J. B. (1995) The effects of halofuginone and salinomycin, alone and in combination, on live performance and skin characteristics of female broilers: influence of a high-proline diet supplemented with ascorbic acid and zinc. Poult. Sci. 74, 383-390.

29. Pitcovski, J., Pinchasov, Y., Meron, M., and Malka, I. (1994) The influence of sex, climate, and body weight on skin tears and muscle damage during plucking of broiler chickens. Poult. Sci. 73, 733-738.

30. Rossi, P., Rutz, F., Anciuti, M. A., Rech, J. L., and Zauk, N. H. F. (2007) Influence of graded levels of organic zinc on growth performance and carcass traits of broilers. J. Appl. Poult. Res. 16, 219-225.

31. Rostan, E. F., DeBuys, H. V., Madey, D. L., and Pinnell, S. R. (2002) Evidence supporting zinc as an important antioxidant for skin. Int. J. Derm. 41, 606-611.

32. Saenmahayak, B. (2007) Complexed trace mineral supplementation of broiler diets. MS thesis, Auburn University, AL, USA.

33. Salim, H. M., Lee, H. R., Jo, C., Lee, S. K., and Lee, B. D. (2008) Zinc in broiler feeding and nutrition. Avian Biol. Res. 1, 5-18

34. Salim, H. M., Lee, H. R., Jo, C., Lee, S. K., and Lee, B. D. (2010) Effect of sources and levels of zinc on the tissue mineral concentration and carcass quality of broilers. Avian Biol. Res. 3, 23-29.

35. SAS (2003) SAS User's Guide: Statistics. Release 9.1. SAS Institute, Inc., Cary, NC.
36. Schleifer, J. (1988) Costly skin tear problem has several major causes. Poult. Dig. December, 580-586.

37. Scott, M. L., Nesheim, M. C., and Yang, R. J. (1982) Essential inorganic elements In: Nutrition of the chicken. Scott, M.L (ed) Humphrey Press Inc, Geneva, NY, pp. 277-382.

38. Smolinska, T. and Korzeniowska, M. (2005) Evaluation of the PSE and DFD abnormalities occurrence in chicken meat. XVII The European Symposium on the Quality of Poultry Meat, Doorwerth, The Netherlands, pp.190-193.

39. Stahl, J. L., Cook, M. E., Sunde, M. L., and Greger, J. L. (1989) Enhanced humoral immunity in progeny chicks from hens fed practical diets supplemented with zinc. Appl. Agric. Sci. 4, 86-89.

40. Tian, G. and Yu, B. (2001) Recent advances in flavour of chicken quality. Chin. Sichuan Anim. Sci. Vet. Med. 28, 5455.

41. Wang, X., Fosmire, G. J., Gay, C. V., and Leach, R. M. (2002) Short-term zinc deficiency inhibits chondrocyte proliferation and induces cell apoptosis in the epiphyseal growth plate of young chickens. J. Nutr. 132, 665-673.

42. Webb, K. E., Wong, E. A., Pan, Y. X., Chen, H., Poole, C. A., Van, L., and Klang, J. E. (2005) The role of peptides in absorption pathways. In: Redefining mineral nutrition. Taylor-Pickard, J. A. and Tucker, L. A. (eds) Nottingham Univ. Press, Nottingham, UK, pp. 197-225.

43. Young, R. J., Edwards, H. M., Jr., and Gillis, M. B. (1958) Studies on zinc in poultry nutrition: Zinc requirement and deficiency symptoms of chicks. Poult. Sci. 37, 1101-1107.

(Received 2010.12.28/Revised 2011.3.30/Accepted 2011.3.31) 